\title{
Formation Mechanism of Magnesium Ammonium Phosphate Stones: A Component Analysis of Urinary Nanocrystallites
}

\author{
Xin-Yuan Sun, Jian-Ming Ouyang, Feng-Xin Wang, and Yu-Shan Xie \\ Institute of Biomineralization and Lithiasis Research, Jinan University, Guangzhou 510632, China \\ Correspondence should be addressed to Jian-Ming Ouyang; toyjm@jnu.edu.cn
}

Received 27 January 2015; Revised 19 March 2015; Accepted 19 March 2015

Academic Editor: Hassan Karimi-Maleh

Copyright ( 2015 Xin-Yuan Sun et al. This is an open access article distributed under the Creative Commons Attribution License, which permits unrestricted use, distribution, and reproduction in any medium, provided the original work is properly cited.

\begin{abstract}
The components of urinary nanocrystallites in patients with magnesium ammonium phosphate (MAP) stones were analyzed by X-ray diffraction (XRD), Fourier-transform infrared (FT-IR) spectrometer, high-resolution transmission electron microscopy (HRTEM), selected area electron diffraction (SAED), fast Fourier transformation (FFT), and energy-dispersive X-ray spectroscopy (EDS). The main components of the stones were MAP hexahydrate $\left(\mathrm{MAP} \cdot 6 \mathrm{H}_{2} \mathrm{O}\right)$, magnesium hydrogen phosphate trihydrate $\left(\mathrm{MgHPO}_{4} \cdot 3 \mathrm{H}_{2} \mathrm{O}\right)$, and a small amount of calcium phosphate $(\mathrm{CaP})$, while the main components of urinary nanocrystallites were $\mathrm{MgHPO}_{4} \cdot 3 \mathrm{H}_{2} \mathrm{O}, \mathrm{CaP}$, and MAP monohydrate (MAP. $\mathrm{H}_{2} \mathrm{O}$ ). MAP. $\mathrm{H}_{2} \mathrm{O}$ induced the formation of MAP stones as seed crystals. $\mathrm{MgHPO}_{4} \cdot 3 \mathrm{H}_{2} \mathrm{O}$ was accompanied by the appearance of $\mathrm{MAP} \cdot 6 \mathrm{H}_{2} \mathrm{O}$. The formation mechanism of MAP stones and influencing factors were discussed on the basis of the components of urine nanocrystallites. A model diagram of MAP stone formation was also put forward based on the results. Formation of MAP stones was closely related to the presence of high amounts of MAP crystallites in urine. Urinary crystallite condition and changes in urine components could indicate the activity of stone diseases.
\end{abstract}

\section{Introduction}

Urinary stones can be divided into acidic (e.g., uric acid and cystine), neutral (e.g., calcium oxalate $(\mathrm{CaOx})$ ), and alkaline (e.g., magnesium ammonium phosphate (MAP)) stones based on their chemical properties. However, indices that can be used to predict the formation and recurrence risk of renal stones are unavailable. Moreover, the same methods and drugs are used in uroliths without distinction. Consequently, curative effects and lower cured rates differ $[1,2]$.

MAP, the most common component of alkaline stones, contains MAP hexahydrate (struvite, $\mathrm{MgNH}_{4} \mathrm{PO}_{4} \cdot 6 \mathrm{H}_{2} \mathrm{O}$ ) and magnesium hydrogen phosphate trihydrate (newberyite, $\mathrm{MgHPO}_{4} \cdot 3 \mathrm{H}_{2} \mathrm{O}$ ). MAP accounts for approximately $10 \%$ to $15 \%$ of all stone components [3]. Other alkaline stones comprise carbapatite $\left(\mathrm{Ca}_{10}\left(\mathrm{PO}_{4}\right)_{6} \mathrm{CO}_{3}\right)$, hydroxyapatite, and monoammonium urate. MAP is defined as infective stones associated with urinary tract infection. Although the morbidity of infective stones constantly decreases, the recurrent rate of infective stones is higher than that of other stones, and female morbidity is higher than male morbidity [4].
The conditions of urinary crystals are closely related to stone formation $[1,2,5-10]$. On the one hand, the disappearance of specific types of urinary crystallites in urine (e.g., cystine and struvite) demonstrates a recurring trend of reduction in stone formation. On the other hand, the continuous or new appearance of these urinary crystals in urine indicates a continuous risk of stone formation or lithiasis relapse. Detecting crystallite components can help predict renal stone formation and even the formation of different types of stones, thereby providing information on appropriate remedies and personalized treatments.

Nanoscience and nanotechnology represent new and enabling platforms that potentially provide a broad range of novel uses and improved technologies for various scientific applications [11]. Nanomaterials, such as nanoparticles, nanofibers, and nanocomposite, have been widely used [12]. For example, $\mathrm{NaX}$ nanozeolite has been successfully synthesized and used to fabricate novel nonenzymatic $\mathrm{H}_{2} \mathrm{O}_{2}$ sensors [13]. $\mathrm{H}_{2} \mathrm{O}_{2}$ sensors show remarkable analytical performances, including a wide linear range, low detection limit, rapid response, and high sensitivity toward the detection of $\mathrm{H}_{2} \mathrm{O}_{2}$. Biosensors 
have also been modified with carbon nanotubes (CNTs) [1416]. For example, Karimi-Maleh et al. [14] developed a carbon paste electrode modified with $\mathrm{NiO} / \mathrm{CNTs}$ nanocomposite and an organic compound (9,10-dihydro-9,10-ethanoanthracene11,12-dicarboximido)-4-ethylbenzene-1,2-diol that can be used to accurately determine cysteamine, nicotinamide adenine dinucleotide, and folic acid in biological and pharmaceutical samples. A ZnO/CNT nanocomposite/catechol derivative modified electrode exhibits excellent electrocatalytic oxidization activity of glutathione and amoxicillin in real samples [12]. A quartz crystal microbalance (QCM) nanosensor has also been developed to detect kaempferol in real time [17].

Photocatalysis is another potential application of nanomaterials. A novel composite containing silver nanoparticles and colemanite ore waste was synthesized and demonstrated as an effective material in adsorption and photocatalysis to remove reactive yellow 86 and reactive red 2 from aqueous solutions in single and binary dye systems [18]. Yola et al. [19] synthesized $\mathrm{TiO}_{2}$ nanoparticles that involve boron enrichment waste $\left(\mathrm{TiO}_{2}-\mathrm{BEW}\right)$ and showed that $\mathrm{TiO}_{2}$ - $\mathrm{BEW}$ can be used as an efficient photocatalyst for atrazine degradation.

The first step in the formation of urinary stones is the nucleation of urinary minerals from supersaturated urine. The formed nucleus (generally less than $10 \mathrm{~nm}$ ) grows and/or aggregates to a pathological size (several tens of microns). These crystallites are then retained in the urinary tract or fixed by urinary tract organization, forming urinary stones (millimeters to several centimeters) [20]. Therefore, morphological characteristics, composition, and crystal structures of urinary nanocrystallites are important factors of stone formation $[21,22]$. To further investigate the relationship between urinary nanocrystallite properties and magnesium ammonium phosphate (MAP) stone formation, we analyzed the chemical constituents of urinary nanocrystallites in six patients with MAP stones through high-resolution transmission electron microscopy (HRTEM), fast Fourier transformation (FFT), selected area electron diffraction (SAED), and energy-dispersive X-ray spectroscopy (EDS). The relationship between urinary crystallite components and MAP stone formation was discussed. Our results can provide insights into the exploration of preventing renal calculi formation from a chemical perspective.

\section{Materials and Methods}

2.1. Reagents and Instruments. Absolute ethanol and sodium azide $\left(\mathrm{NaN}_{3}\right)$ were of analytical purity. Glass vessels were cleaned with double-distilled water.

TEM was conducted on a HRTEM (JOEL 2100F) with a maximum acceleration voltage of $200 \mathrm{kV}$ and lattice resolution of 0.19 . To determine the morphology, component, element, and crystal structure of urinary nanocrystallites, we performed HRTEM, fast Fourier transformation (FFT), SEAD, and EDS of the HRTEM. FFT analysis in the Digital Micrograph software was also conducted to obtain the patterns. X-ray diffraction (XRD) results were recorded using a D/max 2400 X-ray diffractometer (Rigaku, Tokyo, Japan) with Ni-filtered $\mathrm{Cu}$ Ka radiation $(k=1.54 \AA$ ) at a scanning rate of $2^{\circ} \mathrm{min}^{-1}(40 \mathrm{kV}, 30 \mathrm{~mA})$. The divergence and scattering slit was $1^{\circ}$ for the range of $5^{\circ}<2 \theta<60^{\circ}$. A Nicolet 6700 Fouriertransform infrared (FT-IR) spectrometer (Nicolet Company, USA) was also used.

\subsection{Collection and Treatment and Component Detection of} Stones. MAP stones were collected from six patients (2 men and 4 women; mean age $=35.6$ years; range $=23-$ 51 years) with stones after surgery, disinfected with $75 \%$ alcohol, cleared with distilled water, and placed in a dustfree incubator at $45^{\circ} \mathrm{C}$ to dry. The urinary stones were then ground to powder by an agate mortar for XRD and FT-IR characterization. It was shown that the main components of these six stones were MAP.

2.3. Collection and Treatment of Urine. Fasting morning urine samples from the patients with MAP stones were collected. $\mathrm{pH}$ was detected and $2 \% \mathrm{NaN}_{3}$ solution $(10 \mathrm{~mL} / \mathrm{L}$ urine sample) as antiseptic was added to these urine samples. Afterward, $20 \mathrm{~mL}$ of anhydrous alcohol was added to $30 \mathrm{~mL}$ of urine sample to denature the proteins. The solution was stirred for $3 \mathrm{~min}$, left undisturbed for $30 \mathrm{~min}$, and centrifuged at $4000 \mathrm{r} / \mathrm{m}$ for $15 \mathrm{~min}$ to remove the proteins and cell debris from the urine sample. The treated urine was then filtered using a microporous membrane with a pore size of $1.2 \mu \mathrm{m}$ to eliminate the effect of large urinary crystallites. The filtered urine was stored in clean glassware for examination.

2.4. HRTEM Detection of Urinary Nanocrystallites. In the preparation of samples for HRTEM detection, the urine sample was first subjected to ultrasound treatment for $5 \mathrm{~min}$, approximately $5 \mu \mathrm{L}$ of urine was submerged in a copper mesh by a microsyringe, and the urine was preliminarily dried using an absorbent paper from the back of the mesh so as to remove most of the water in urine. After such a treatment, most of the soluble salts (such as $\mathrm{NaCl}$ and urea) in urine were sucked off with the urine by the paper. Then the mesh was stored in a desiccator for $2 \mathrm{~d}$ prior to HRTEM, SAED, and EDS analyses.

2.5. Detection of Magnesium and Phosphate in Urine. The $\mathrm{Mg}^{2+}$ and phosphate concentrations in the urine of healthy control and patients with MAP stones were, respectively, detected using an atomic absorption spectrophotometer (TAS-990) and colorimetric method (molybdate) using spectrum automated analyzer.

\section{Results}

3.1. Component Analysis of MAP Stones. The components of six MAP stones were characterized by XRD and FT-IR spectra. The results are shown in Table 1 . The stones mainly comprised $\mathrm{MAP} \cdot 6 \mathrm{H}_{2} \mathrm{O}$ and small amounts of $\mathrm{MgHPO}_{4} \cdot 3 \mathrm{H}_{2} \mathrm{O}$, $\mathrm{CaP}$, and $\mathrm{COM}$.

3.2. Component Analysis of Urinary Nanocrystallites. The components of urinary nanocrystallites in patients with MAP 
TABLE 1: Statistical analysis of the components of stones, urinary nanocrystallites, and urine of six patients with MAP stones compared with six healthy subjects.

\begin{tabular}{|c|c|c|c|c|c|c|}
\hline Number & Location & Stone component ${ }^{* 1}$ & $\begin{array}{c}\text { Crystallite } \\
\text { component }^{* 2}\end{array}$ & Urine $\mathrm{pH}$ & $\mathrm{Mg}^{2+}(\mathrm{mg} / \mathrm{L})$ & Phosphate $(\mathrm{mg} / \mathrm{L})$ \\
\hline Patient A & Kidney & $\begin{array}{c}67 \% \mathrm{MAP}^{\circ} \cdot 6 \mathrm{H}_{2} \mathrm{O} \\
16 \% \mathrm{MgHPO}_{4} \cdot 3 \mathrm{H}_{2} \mathrm{O} \\
16 \% \mathrm{CaP}\end{array}$ & $\begin{array}{l}\mathrm{MAP} \cdot \mathrm{H}_{2} \mathrm{O} \\
\quad \mathrm{CaP}\end{array}$ & 6.6 & 54.6 & 519 \\
\hline Patient B & Kidney & $\begin{array}{c}76 \% \mathrm{MAP}^{\circ} 6 \mathrm{H}_{2} \mathrm{O} \\
12 \% \mathrm{MgHPO}_{4} \cdot 3 \mathrm{H}_{2} \mathrm{O} \\
12 \% \mathrm{CaP}\end{array}$ & $\begin{array}{c}\mathrm{MgHPO}_{4} \cdot 3 \mathrm{H}_{2} \mathrm{O} \\
\mathrm{CaP}\end{array}$ & 6.8 & 68.1 & 576 \\
\hline Patient C & Kidney & $\begin{array}{c}67 \% \mathrm{MAP}^{2} 6 \mathrm{H}_{2} \mathrm{O} \\
16 \% \mathrm{MgHPO}_{4} \cdot 3 \mathrm{H}_{2} \mathrm{O} \\
16 \% \mathrm{CaP}\end{array}$ & $\begin{array}{c}\mathrm{MgHPO}_{4} \cdot 3 \mathrm{H}_{2} \mathrm{O} \\
\mathrm{COM} \\
\mathrm{MAP} \cdot \mathrm{H}_{2} \mathrm{O}\end{array}$ & 6.4 & 52.1 & 539 \\
\hline Patient D & Bladder & $\begin{array}{c}75 \% \mathrm{MAP}^{2} 6 \mathrm{H}_{2} \mathrm{O} \\
25 \% \mathrm{COM}\end{array}$ & $\begin{array}{c}\mathrm{MgHPO}_{4} \cdot 3 \mathrm{H}_{2} \mathrm{O}, \\
\mathrm{MAP} \cdot \mathrm{H}_{2} \mathrm{O} \\
\mathrm{CaP}\end{array}$ & 6.1 & 58.5 & 611 \\
\hline Patient E & Kidney & $\begin{array}{c}78 \% \mathrm{MAP}^{2} 6 \mathrm{H}_{2} \mathrm{O} \\
22 \% \mathrm{COM}\end{array}$ & $\begin{array}{c}\mathrm{MAP} \cdot \mathrm{H}_{2} \mathrm{O} \\
\mathrm{MgHPO}_{4} \cdot 3 \mathrm{H}_{2} \mathrm{O} \\
\end{array}$ & 6.6 & 61.3 & 580 \\
\hline Patient F & Bladder & $\begin{array}{c}65 \% \mathrm{MAP}^{\circ} 6 \mathrm{H}_{2} \mathrm{O} \\
35 \% \mathrm{COM}\end{array}$ & $\begin{array}{c}\mathrm{MAP} \cdot \mathrm{H}_{2} \mathrm{O} \\
\mathrm{COM} \\
\end{array}$ & 6.4 & 58.1 & 478 \\
\hline $\begin{array}{l}\text { Average value of six } \\
\text { patients }\end{array}$ & & & & $6.5 \pm 0.4$ & $58.8 \pm 13.1$ & $550 \pm 72$ \\
\hline $\begin{array}{l}\text { Average value of six } \\
\text { healthy subjects }\end{array}$ & & & $\begin{array}{c}\mathrm{UA} \\
\mathrm{COD} \\
\mathrm{MAP} \cdot \mathrm{H}_{2} \mathrm{O}\end{array}$ & $6.0 \pm 0.3$ & $74.1 \pm 23.2$ & $441 \pm 59$ \\
\hline
\end{tabular}

Notes. ${ }^{* 1}$ Stone composition was detected by XRD and FT-IR spectra. MAP: magnesium ammonium phosphate; $\mathrm{MgHPO}_{4} \cdot 3 \mathrm{H}_{2} \mathrm{O}$ : magnesium hydrogen phosphate trihydrate; CaP: calcium phosphate. UA: uric acid; COM: calcium oxalate monohydrate; COD: calcium oxalate dihydrate.

${ }^{* 2}$ Crystallite composition was detected by HRTEM, SAED, EDS, and XRD and was arranged in decreasing order.

stones were simultaneously analyzed through a combination of HRTEM, SAED, EDS, and XRD. These nanocrystallites mainly comprised MAP. $\mathrm{H}_{2} \mathrm{O}, \mathrm{MgHPO}_{4} \cdot 3 \mathrm{H}_{2} \mathrm{O}$, and $\mathrm{CaP}$. Namely, MAP. $\mathrm{H}_{2} \mathrm{O}$ was the main component of urinary nanocrystallites and MAP. $6 \mathrm{H}_{2} \mathrm{O}$ was the main component of stones.

3.2.1. HRTEM Analysis of Urinary Nanocrystallites. Figure 1 shows the HRTEM images obtained in different areas of the urinary nanocrystallites. To analyze the clear lattice fringes in random selection, we detected the spacing of lattice fringe at $d=4.72 \AA$, which was assigned to (110) plane of MAP. $\mathrm{H}_{2} \mathrm{O}$ in Figure 1(a). In Figure 1(b) we also detected the lattice fringes at $d=4.61$ and $4.49 \AA$, which were assigned to (210) and (102) planes of $\mathrm{MgHPO}_{4} \cdot 3 \mathrm{H}_{2} \mathrm{O}$, respectively. Namely, the main components of urinary nanocrystallites in patients with MAP stones were $\mathrm{MAP} \cdot \mathrm{H}_{2} \mathrm{O}$ and $\mathrm{MgHPO}_{4} \cdot 3 \mathrm{H}_{2} \mathrm{O}$.

3.2.2. SAED Analysis of Urinary Nanocrystallites. SAED analysis was conducted to further characterize the components of some urinary nanocrystallites (Figure 2). The appearance of a series of diffraction points or diffraction rings demonstrated that the sample is monocrystal or polycrystal [23, 24]. The diffraction data were indexed and compared with the PDF standard card [25]. Figure 2 showed an interplanar spacing of $4.71,2.37,2.19,1.79,1.70$, and $1.58 \AA$, which were assigned to the (021), (114), (214), (144), (610), and (206) planes of $\mathrm{MgHPO}_{4} \cdot 3 \mathrm{H}_{2} \mathrm{O}$, respectively. We also detected 2.88, 1.89, and $1.44 \AA$, which were assigned to the (0210), (238), and (0420) planes of $\mathrm{CaP}$, respectively. Interplanar spacings of 2.50 and $1.49 \AA$ were also detected and assigned to (031) and (250) planes of MAP. $\mathrm{H}_{2} \mathrm{O}$. The SAED results showed the presence of $\mathrm{MgHPO}_{4} \cdot 3 \mathrm{H}_{2} \mathrm{O}, \mathrm{CaP}$, and $\mathrm{MAP} \cdot \mathrm{H}_{2} \mathrm{O}$ in urinary crystallites. These results are consistent with those of HRTEM in Figure 1.

3.2.3. EDS Analysis of Urinary Nanocrystallites. EDS of urinary crystallites was performed to further evaluate their components. Figure 3 shows the EDS distribution in samples from two representative patients with MAP stones. N, O, $\mathrm{Mg}, \mathrm{P}$, and Ca were detected (Figure 3(a)). The corresponding atomic ratios were $17.80 \%, 56.48 \%, 0.98 \%, 12.06 \%$, and $0.71 \%$ (Figure 3(b)). C, O, P, Mg, and Ca were detected (Figure 3(c)). The respective atomic ratios were $43.69 \%, 24.60 \%, 6.63 \%$, $3.18 \%$, and $2.13 \%$ (Figure $3(\mathrm{~d})$ ). These results indicated that the urinary nanocrystallites contained MAP and CaP.

Marickar et al. [26] also detected the absorption peaks of $\mathrm{C}, \mathrm{N}, \mathrm{O}, \mathrm{P}, \mathrm{Mg}$, and $\mathrm{Ca}$ with atomic ratios of $64.71 \%, 3.34 \%$, $19.64 \%, 6.95 \%, 4.87 \%$, and $0.23 \%$, respectively, in the EDS spectra of MAP crystals (approximately $20 \mu \mathrm{m}$ ) in urine. The EDS result of nanosized MAP crystallites is consistent with that of microsized crystals.

3.3. Component Comparison of Urinary Nanocrystallites and Urine between Patients with MAP Stones and Healthy Subjects. Table 1 shows the statistical analysis results of 


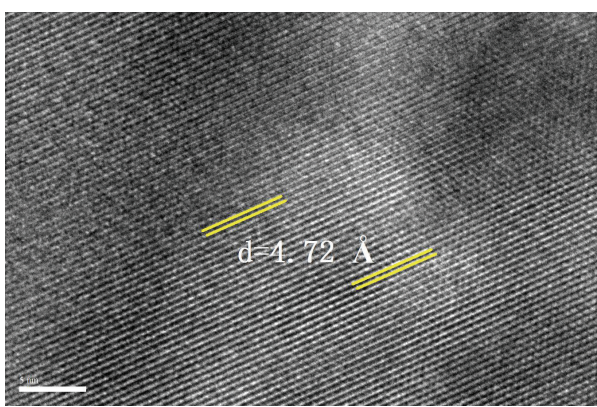

(a)

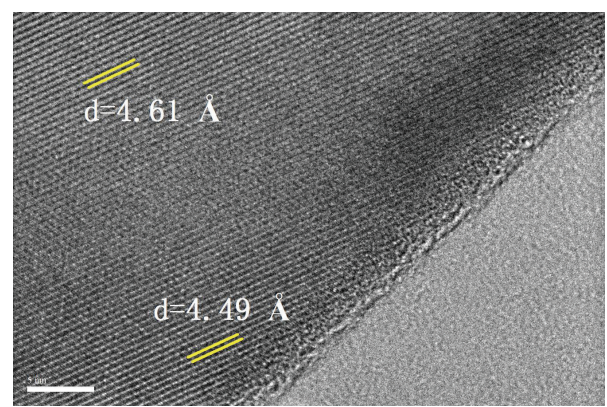

(b)

Figure 1: HRTEM images of urinary nanocrystallites in patients with MAP stones. The bar: $5 \mathrm{~nm}$. (a) Patient A; (b) patient B. Scale bars: $5 \mathrm{~nm}$.

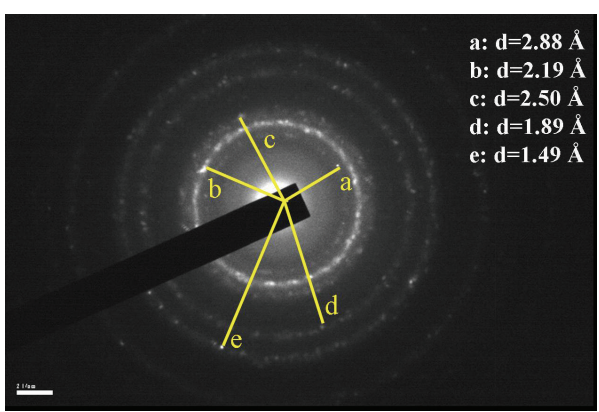

(a)

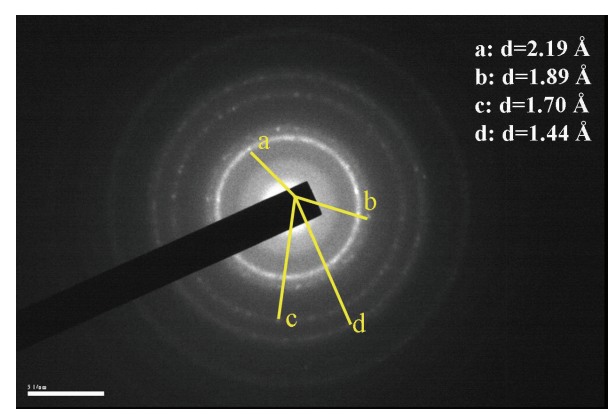

(b)

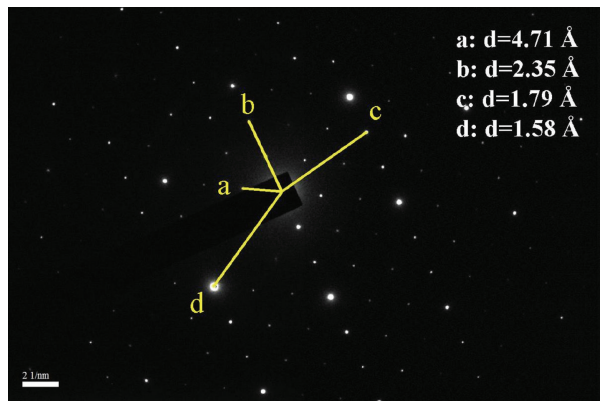

(c)

FIGURE 2: SAED images of urinary nanocrystallites in patients with MAP stones. (a) Patient A; (b) patient B; (c) patient C. Scale bars: (a, c) $21 / \mathrm{nm}$; (b) $51 / \mathrm{nm}$.

the components of urinary crystallites of the six patients with MAP stones based on the comprehensive measurement results of XRD, SAED, FFT, and EDS. The urinary crystallites of six healthy subjects without stones were also obtained. The urinary nanocrystallites of patients with MAP stones were significantly different from those in healthy subjects. Large amounts of MAP. $\mathrm{H}_{2} \mathrm{O}$ and $\mathrm{MgHPO}_{4} \cdot 3 \mathrm{H}_{2} \mathrm{O}$ crystallites were detected in the urine of patients. By contrast, a small amount of MAP. $\mathrm{H}_{2} \mathrm{O}$ was found in the urine of healthy subjects. The main components of healthy urine samples were UA and COD crystallites.

Urine $\mathrm{pH}$ and phosphate concentration in patients with MAP stones $(6.5 \pm 0.4,550 \pm 72 \mathrm{mg} / \mathrm{L})$ were higher than those of healthy subjects $(6.0 \pm 0.3,441 \pm 59 \mathrm{mg} / \mathrm{L})$, respectively.
However, $\mathrm{Mg}^{2+}$ concentration $(58.8 \pm 13.1 \mathrm{mg} / \mathrm{L})$ was apparently lower than that of healthy subjects $(74.1 \pm 23.2 \mathrm{mg} / \mathrm{L})$ (Table 1).

\section{Discussion}

4.1. Status of the Clinical Diagnosis of Kidney Stones. In clinics, kidney stones are often diagnosed with the following methods: (a) abdominal plain sheet (KUB) diagnosis; (b) intravenous pyelography (IVP); and (c) B super diagnosis. In some cases, magnetic resonance urography (MRU), singlephoton emission computed tomography (SPECT) check, antegrade pyelography, and CT examination are also conducted. These methods are mainly limited to detecting stones 

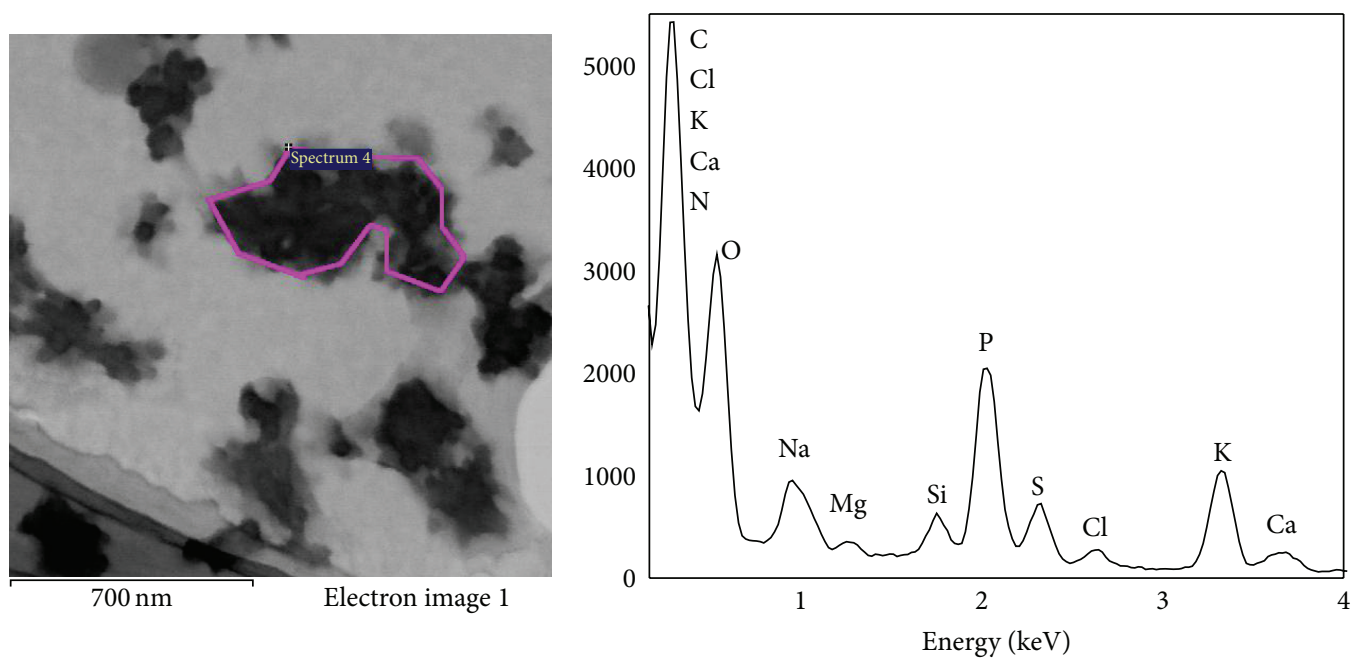

$\begin{array}{ccc}\text { Element } & \text { Weight (\%) } & \text { Atomic }(\%) \\ \mathrm{N} & 12.53 & 17.80 \\ \mathrm{O} & 45.40 & 56.48 \\ \mathrm{Mg} & 1.14 & 0.98 \\ \mathrm{P} & 18.77 & 12.06 \\ \mathrm{Ca} & 1.42 & 0.71\end{array}$

(a)
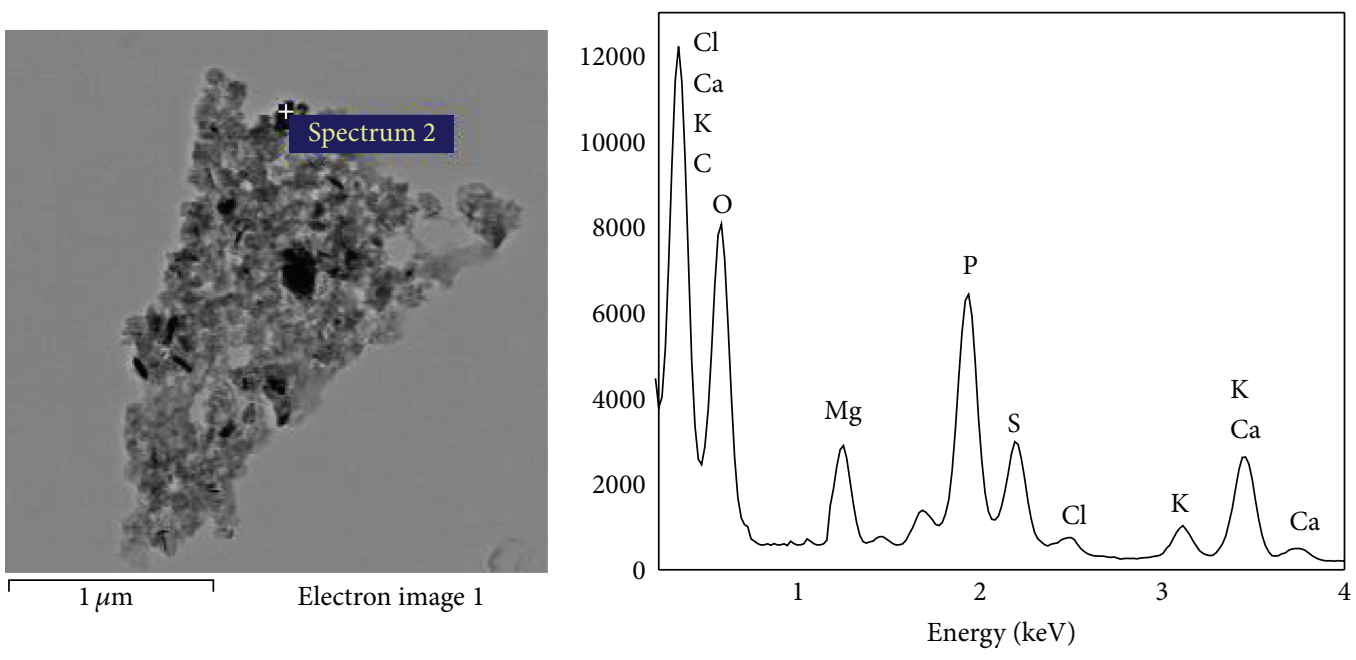

$\begin{array}{ccc}\text { Element } & \text { Weight (\%) } & \text { Atomic (\%) } \\ \text { C K } & 21.70 & 43.69 \\ \text { O K } & 16.27 & 24.60 \\ \text { Mg K } & 3.20 & 3.18 \\ \text { P K } & 8.49 & 6.63 \\ \text { Ca K } & 3.52 & 2.13\end{array}$

(c)

(d)

FIGURE 3: HRTEM images and EDS analysis of urinary nanocrystallites in patients with MAP stones. (a, c) HRTEM image; (b, d) element distribution. (a, b) Patient A; (c, d) patient B. Scale bars: (a) $700 \mathrm{~nm}$; (b) $1000 \mathrm{~nm}$.

only after these stones are formed; as such, the presence or occurrence of stones cannot be successfully predicted or early diagnosis cannot be performed.

Therefore, the following aspects should be considered: (a) the occurrence of urinary stones should be detected rapidly and conveniently before these stones are formed, thereby preventing stone formation, and (b) the type of stone should be determined (according to the main component) before stones are removed and treated. For example, clinicians can choose different shock frequencies and shock time in 
extracorporeal shock wave lithotripsy (ESWL) according to the type of urinary stones because the hardness of stones varies in terms of different components. The relative hardness of different types of stones is listed as follows:

COM ( 4 to 5 ) > cystine, apatite ( 3 to 5 ) > uric acid (2.5) $>$ calcium hydrophosphate, magnesium ammonium phosphate, or COD (2.0).

Different therapeutic methods can be used to treat different types of stones. (a) For acidic stones (e.g., uric acid and cystine), alkaline medicines, such as tris(hydroxymethyl)aminomethane (THAM), are used to alkalize urine ( $\mathrm{pH}$ $=6.5$ to 6.8). Potassium citrate also increases urine $\mathrm{pH}$. (b) For alkaline stones (e.g., struvite), L-methionine can be used to acidify urine. Trimethoprim-sulfamethoxazole can be used to prevent urinary tract infection or acetohydroxamic acid can be administered to control the concentration of urease. (c) For neutral stones (e.g., calcium oxalate), hydrogen sodium potassium citrate, potassium citrate, or dihydrochlorothiazide can be used to carry out defensive treatment.

Urinary nanocrystallites highly indicate stone diseases and can be used to predict stone recurrence; their physicochemical properties can also be evaluated in terms of potential clinical values because crystalluria precipitation results from diverse factors, which act in urine to trigger crystal formation, including inhibitors and promoters, as well as measured and unmeasured trigger factors [8-10]. Urinary crystallites exhibit a higher accuracy of predicting stone diseases than daily urine volume, 24-hour calcium excretion, or urine calcium or oxalate concentration. However, it was also reported that the presence of crystalluria did not enable an efficient characterization of recurrent stone formers because crystals are found in the urine of healthy men and lithogenic patients [27-30]. The particle size of the former is not always smaller than that of the latter; the pathogenesis of male and female patients may differ.

However, all of the investigated crystals were at a micron level; most of these crystals are frequently affected by food metabolism. Moreover, the majority of tissue debris and apoptotic cells in urine are in the same order of magnitude as urinary crystals [31]; thus, clinical application of crystalluria determination is limited to a high extent. Therefore, this study focused on the properties of urine nanocrystallites, expecting to perform early diagnosis for MAP stones.

\subsection{Urinary Nanocrystallite Components and Stone Forma-} tion. The results of this study showed that urinary nanocrystallites could indicate stone diseases. The results of HRTEM (Figure 1), SAED (Figure 2), and EDS (Figure 3) showed that the main components of urinary nanocrystallites in patients with MAP stones were MAP. $\mathrm{H}_{2} \mathrm{O}, \mathrm{MgHPO}_{4} \cdot 3 \mathrm{H}_{2} \mathrm{O}$, and small amounts of $\mathrm{CaP}$ or $\mathrm{COM}$, which significantly differed from those in healthy subjects. Therefore, the properties of urinary crystallites should be detected to help predict the formation of stone and certain types of urinary stone; as such, relevant information could be used as basis for appropriate remedies and personalized treatments.

MAP is a common component in the urine of healthy subjects but plays an insignificant role for its unsaturation in healthy subjects' urine $[32,33]$. However, compared with the urine of controls and patients with other stones, the proportions of $\mathrm{MAP} \cdot 6 \mathrm{H}_{2} \mathrm{O}$ and $\mathrm{MgHPO}_{4} \cdot 3 \mathrm{H}_{2} \mathrm{O}$ crystals increased in the urine of patients with MAP stones. We have detected the concentration of $\mathrm{Mg}^{2+}$ and phosphate in the urine of patients with MAP stones compared with those of the control subjects and patients with $\mathrm{CaOx}$ stones. The respective concentrations of $\mathrm{Mg}^{2+}$ were $74.1 \pm 23.2,58.8 \pm$ 13.1 , and $62.1 \pm 35 \mathrm{mg} / \mathrm{L}$. The lowest $\mathrm{Mg}^{2+}$ concentration was found in the urine of patients with MAP stones. He et al. [34] also reported that the percentage of hypomagnesiuria in patients with infectious stones was $55.6 \%$, which is higher than that in $\mathrm{CaOx}$ group (40.3\%) and UA group (36.7\%). The respective phosphate concentration is $441 \pm 59,550 \pm 72$, and $481 \pm 89 \mathrm{mg} / \mathrm{L}$. Srinivasan et al. [35] also found that the concentration of urine phosphate was $919 \pm 67,801 \pm 57$, $779 \pm 81$, and $754 \pm 114 \mathrm{mg} / 24 \mathrm{~h}$, respectively, in urine of patients with MAP, $\mathrm{CaOx}$, and UA stones, and in urine of healthy controls. The highest phosphate concentration was found in the urine of patients with MAP stones.

The main components of stones were MAP. $6 \mathrm{H}_{2} \mathrm{O}$ and $\mathrm{MgHPO}_{4} \cdot 3 \mathrm{H}_{2} \mathrm{O}$, whereas those of urinary nanocrystallites were $\mathrm{MgHPO}_{4} \cdot 3 \mathrm{H}_{2} \mathrm{O}$ and $\mathrm{MAP} \cdot \mathrm{H}_{2} \mathrm{O}$. The reasons are as follows.

(1) $\mathrm{MAP} \cdot \mathrm{H}_{2} \mathrm{O}$ induces the formation of $\mathrm{MAP} \cdot 6 \mathrm{H}_{2} \mathrm{O}$ stones (struvite) as seed crystals. This process is fast and confers difficulty in detecting MAP. $\mathrm{H}_{2} \mathrm{O}$ by conventional methods. Hence, MAP. $\mathrm{H}_{2} \mathrm{O}$ was not detected in the stones. However, a large amount of MAP. $\mathrm{H}_{2} \mathrm{O}$ was detected in urinary nanocrystallites. In vitro experiment revealed that an MAP. $\mathrm{H}_{2} \mathrm{O}$ seed crystal is used as crystal growth templates in a mixed solution. This solution contains urea and the bacterium Proteus mirabilis. Porous quasi-spherical particles of MAP. $6 \mathrm{H}_{2} \mathrm{O}$ with diameters ranging from $3 \mu \mathrm{m}$ to $6 \mu \mathrm{m}$ are produced after 3 days of reaction [36].

(2) The formation of various magnesium phosphates was closely related to supersaturation degree, $\mathrm{Mg}^{2+}, \mathrm{NH}_{4}{ }^{+}$, and $\mathrm{PO}_{4}{ }^{3-}$ concentrations, and $\mathrm{pH}$ of urine system. $\mathrm{MgHPO}_{4} \cdot 3 \mathrm{H}_{2} \mathrm{O}$ unlikely crystallizes as the first phase in human stones. This process often accompanies or follows the precipitation of MAP. $6 \mathrm{H}_{2} \mathrm{O}$ and is randomly distributed among MAP stones [37].

(3) $\mathrm{MAP} \cdot 6 \mathrm{H}_{2} \mathrm{O}$ is thermodynamically unstable in urine and easy to transform into $\mathrm{MgHPO}_{4} \cdot 3 \mathrm{H}_{2} \mathrm{O}$. MAP. $6 \mathrm{H}_{2} \mathrm{O}$ starts dehydrating even at room temperature. This substance can lose some ammonia molecules and crystallization water molecules, thereby transforming into $\mathrm{MgHPO}_{4} \cdot 3 \mathrm{H}_{2} \mathrm{O}$ and MAP. $\mathrm{H}_{2} \mathrm{O}$. As decomposition proceeds, MAP $6 \mathrm{H}_{2} \mathrm{O}$ transforms into dehydrated newberyite $\left(\mathrm{MgHPO}_{4}\right.$, $5 \%$ ) and dehydrated struvite (MAP, 95\%) [38].

4.3. The Formation Mechanism of MAP Stones. After urine was infected by bacteria, urea in urine is decomposed by 


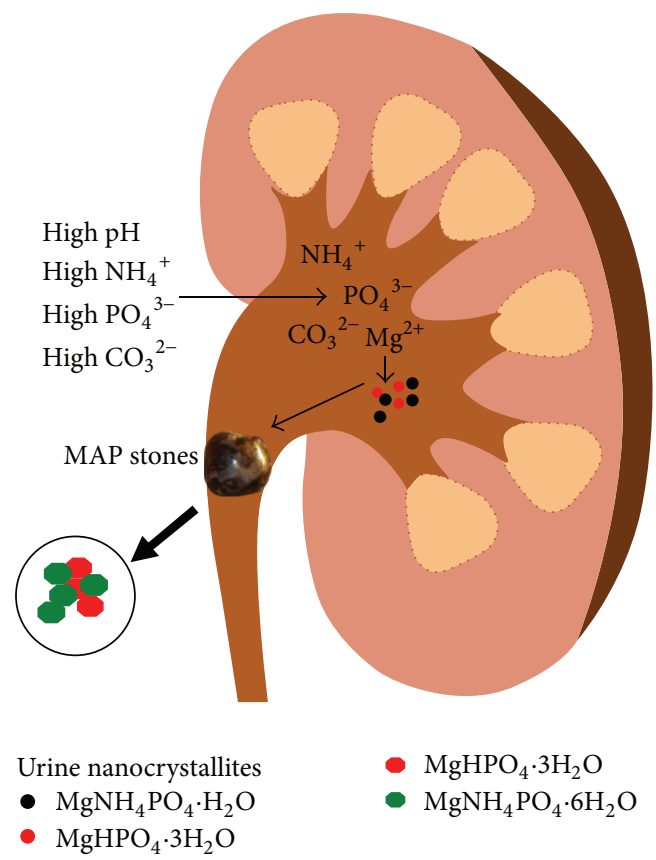

FIgURE 4: Model diagram of MAP stone formation.

urease produced from bacteria, leading to a significant increase in urine $\mathrm{pH}[36]$; as a result, $\mathrm{NH}_{4}{ }^{+}, \mathrm{CO}_{3}{ }^{2-}$, and $\mathrm{PO}_{4}{ }^{3-}$ concentrations in urine rapidly increase.

The average value of urine $\mathrm{pH}$ of the six patients with MAP stones was $6.5 \pm 0.4$, which was higher than that of patients with uric acid stones $(\mathrm{pH}=5.3 \pm 0.3)$ and the healthy controls $(\mathrm{pH}=6.0 \pm 0.3)[2]$. At urine $\mathrm{pH} 6.8, \mathrm{PO}_{4}{ }^{3-}, \mathrm{CO}_{3}{ }^{2-}$, and $\mathrm{NH}_{4}{ }^{+}$combine with calcium ions in urine, and calcium phosphate and carbon-apatite are formed. At urine $\mathrm{pH} \mathrm{7.2,}$ these ions interact with $\mathrm{Mg}^{2+}$ ions adsorbed on the biofilm surface of bacteria. Struvite-calcium phosphate precipitates are formed, providing a nidus for crystal nucleation, growth, and aggregation. As MAP saturation in urine increases, crystals constantly precipitate on bacteria, forming struvite stones $[39,40]$. Furthermore, calcium phosphates induce the development of calcium oxalate monohydrate crystals through heterogeneous nucleation [41, 42]. Lee et al. [43] performed TGA and EDS to identify the components on surface and interior layer of MAP calculi; the results show that the interior layer is composed of $64 \%$ MAP and $36 \%$ apatite, whereas the surface is composed of calcium oxalate $(\mathrm{CaOx})$.

Based on these findings, a model diagram of MAP stone formation is shown in Figure 4. The formation of MAP stones was closely related not only to high concentrations of phosphate and $\mathrm{pH}$ in urine but also to the properties of urinary nanocrystallites. Urinary tract infections cause high urinary $\mathrm{pH}$, high $\mathrm{NH}_{4}{ }^{+}, \mathrm{CO}_{3}{ }^{2-}$, and $\mathrm{PO}_{4}{ }^{3-}$ concentrations, as well as the presence of $\mathrm{Mg}^{2+}$, resulting in the appearance of nanocrystallites of $\mathrm{MAP} \cdot \mathrm{H}_{2} \mathrm{O}, \mathrm{MgHPO}_{4} \cdot 3 \mathrm{H}_{2} \mathrm{O}$, and $\mathrm{CaP}$, among others; thus, MAP stones composed of $\mathrm{MAP} \cdot 6 \mathrm{H}_{2} \mathrm{O}$ and $\mathrm{MgHPO}_{4} \cdot 3 \mathrm{H}_{2} \mathrm{O}$ are formed.
4.4. The Advantage of HRTEM in Detection of Urinary Nanocrystallites. X-ray diffraction (XRD) is a commonly used tool to identify material components. Previous studies $[1,2]$ determined the components of urinary nanocrystallites in patients with $\mathrm{CaOx}$ stones and uric acid stones through XRD and Fourier-transform infrared (FT-IR) spectrometry. However, XRD and FT-IR analyses exhibit disadvantages. For instance, a large sample quantity was required for XRD and FT-IR analyses; the spectral baseline was very high when a small amount of samples was used. XRD and FTIR detection results provided comprehensive data of all crystallites; thus, a component of $<5 \%$ was difficult to be detected. The absorption peaks of such low contents $(<5 \%)$ were not visible when the content of one component in the crystallites was extremely high. This low content may act as a nidus to induce crystal growth in renal stone formation.

By contrast, the combination of HRTEM, FFT, SAED, and EDS can be applied to accurately analyze the components of a single nanocrystallite in urine, even small crystallites with the size of several nanometers. Thus, these methods can provide information on initial renal stone formation.

\section{Conclusions}

A combination of HRTEM, SAED, EDS, and XRD was performed to detect the components of urinary nanocrystallites in six patients with MAP stones. The components of urinary nanocrystallites were compared with stone components. Stones mainly comprised $\mathrm{MAP} \cdot 6 \mathrm{H}_{2} \mathrm{O}, \mathrm{MgHPO}_{4} \cdot 3 \mathrm{H}_{2} \mathrm{O}$, and a small amount of $\mathrm{CaP}$; urinary nanocrystallites mainly comprised $\mathrm{MgHPO}_{4} \cdot 3 \mathrm{H}_{2} \mathrm{O}, \mathrm{MAP} \cdot \mathrm{H}_{2} \mathrm{O}$, and $\mathrm{CaP}$. The formation of MAP stones was closely related to the presence of high amounts of $\mathrm{MgHPO}_{4} \cdot 3 \mathrm{H}_{2} \mathrm{O}$ and $\mathrm{MAP} \cdot \mathrm{H}_{2} \mathrm{O}$ crystals in urine. MAP. $\mathrm{H}_{2} \mathrm{O}$ induced the formation of $\mathrm{MAP} \cdot 6 \mathrm{H}_{2} \mathrm{O}$ as seed crystals. $\mathrm{MgHPO}_{4} \cdot 3 \mathrm{H}_{2} \mathrm{O}$ was often accompanied by the precipitation of MAP. $6 \mathrm{H}_{2} \mathrm{O}$. The combination of HRTEM, SAED, EDS, and XRD can be applied to accurately analyze the components of urinary nanocrystallites. This study provided insights into the formation mechanism of magnesium ammonium phosphate stones.

\section{Conflict of Interests}

The authors declare that there is no conflict of interests regarding the publication of this paper.

\section{Acknowledgments}

This research work was supported by the Natural Science Foundation of China (81170649) and the Natural Science Foundation of Guangdong Province.

\section{References}

[1] C.-Y. Duan, Z.-Y. Xia, G.-N. Zhang, B.-S. Gui, J.-F. Xue, and J.-M. Ouyang, "Changes in urinary nanocrystallites in calcium oxalate stone formers before and after potassium citrate intake," International Journal of Nanomedicine, vol. 8, pp. 909-918, 2013. 
[2] G.-N. Zhang, J.-M. Ouyang, J.-F. Xue, and Y.-F. Shang, "Property changes of urinary nanocrystallites and urine of uric acid stone formers after taking potassium citrate," Materials Science and Engineering C, vol. 33, no. 7, pp. 4039-4045, 2013.

[3] C. A. A. Ghumman, O. M. T. Carreira, A. M. C. Moutinho, A. Tolstogouzov, V. Vassilenko, and O. M. N. D. Teodoro, "Identification of human calculi with time-of-flight secondary ion mass spectrometry," Rapid Communications in Mass Spectrometry, vol. 24, no. 2, pp. 185-190, 2010.

[4] T. Knoll, A. B. Schubert, P. D. Fahlenkamp, D. B. Leusmann, G. Wendt-Nordahl, and G. Schubert, "Urolithiasis through the ages: data on more than 200,000 urinary stone analyses," The Journal of Urology, vol. 185, no. 4, pp. 1304-1311, 2011.

[5] S. Verdesca, G. B. Fogazzi, G. Garigali, P. Messa, and M. Daudon, "Crystalluria: prevalence, different types of crystals and the role of infrared spectroscopy," Clinical Chemistry and Laboratory Medicine, vol. 49, no. 3, pp. 515-520, 2011.

[6] J. M. Baumann, B. Affolter, and R. Meyer, "Crystal sedimentation and stone formation," Urological Research, vol. 38, no. 1, pp. 21-27, 2010.

[7] B. A. Vervaet, A. Verhulst, S. E. Dauwe, M. E. de Broe, and P. C. D'Haese, "An active renal crystal clearance mechanism in rat and man," Kidney International, vol. 75, no. 1, pp. 41-51, 2009.

[8] M. Daudona and P. Jungers, "Clinical value of crystalluria and quantitative morphoconstitutional analysis of urinary calculi," Nephron-Physiology, vol. 98, no. 2, pp. p31-p36, 2004.

[9] M. Daudon, C. Hennequin, G. Boujelben, B. Lacour, and P. Jungers, "Serial crystalluria determination and the risk of recurrence in calcium stone formers," Kidney International, vol. 67, no. 5, pp. 1934-1943, 2005.

[10] M. Daudon, F. Cohen-Solal, F. Barbey, M.-F. Gagnadoux, B. Knebelmann, and P. Jungers, "Cystine crystal volume determination: a useful tool in the management of cystinuric patients," Urological Research, vol. 31, no. 3, pp. 207-211, 2003.

[11] A. Pahlavan, H. Karimi-Maleh, F. Karimi et al., "Application of $\mathrm{CdO}$ nanoparticle ionic liquid modified carbon paste electrode as a high sensitive biosensor for square wave voltammetric determination of NADH," Materials Science and Engineering C, vol. 45, pp. 210-215, 2014.

[12] H. Karimi-Maleh, F. Tahernejad-Javazmi, V. K. Gupta, H. Ahmar, and M. H. Asadi, "A novel biosensor for liquid phase determination of glutathione and amoxicillin in biological and pharmaceutical samples using a $\mathrm{ZnO} / \mathrm{CNTs}$ nanocomposite/catechol derivative modified electrode," Journal of Molecular Liquids, vol. 196, pp. 258-263, 2014.

[13] S. N. Azizi, S. Ghasemi, and S. Kavian, "Synthesis and characterization of $\mathrm{NaX}$ nanozeolite using stem sweep as silica source and application of Ag-modified nanozeolite in electrocatalytic reduction of $\mathrm{H}_{2} \mathrm{O}_{2}$," Biosensors and Bioelectronics, vol. 62, pp. 1-7, 2014.

[14] H. Karimi-Maleh, P. Biparva, and M. Hatami, "A novel modified carbon paste electrode based on $\mathrm{NiO} / \mathrm{CNT}$ nanocomposite and (9, 10-dihydro-9, 10-ethanoanthracene-11, 12-dicarboximido)4-ethylbenzene-1, 2-diol as a mediator for simultaneous determination of cysteamine, nicotinamide adenine dinucleotide and folic acid," Biosensors and Bioelectronics, vol. 48, pp. 270275, 2013.

[15] N. K. Mehra, V. Mishra, and N. K. Jain, "A review of ligand tethered surface engineered carbon nanotubes," Biomaterials, vol. 35, no. 4, pp. 1267-1283, 2014.
[16] H. Karimi-Maleh, F. Tahernejad-Javazmi, M. Daryanavard, H. Hadadzadeh, A. A. Ensafi, and M. Abbasghorbani, "Electrocatalytic and simultaneous determination of ascorbic acid, nicotinamide adenine dinucleotide and folic acid at ruthenium(II) complex-ZnO/CNTs nanocomposite modified carbon paste electrode," Electroanalysis, vol. 26, no. 5, pp. 962-970, 2014.

[17] V. K. Gupta, M. L. Yola, and N. Atar, "A novel molecular imprinted nanosensor based quartz crystal microbalance for determination of kaempferol," Sensors and Actuators B: Chemical, vol. 194, pp. 79-85, 2014.

[18] M. L. Yola, T. Eren, N. Atar, and S. Wang, "Adsorptive and photocatalytic removal of reactive dyes by silver nanoparticlecolemanite ore waste," Chemical Engineering Journal, vol. 242, pp. 333-340, 2014.

[19] M. L. Yola, T. Eren, and N. Atar, "A novel efficient photocatalyst based on $\mathrm{TiO}_{2}$ nanoparticles involved boron enrichment waste for photocatalytic degradation of atrazine," Chemical Engineering Journal, vol. 250, pp. 288-294, 2014.

[20] J.-M. Ouyang, Z.-Y. Xia, G.-N. Zhang, and H.-Q. Chen, "Nanocrystallites in urine and their relationship with the formation of kidney stones," Reviews in Inorganic Chemistry, vol. 32, no. 2-4, pp. 101-110, 2012.

[21] J. Gao, J. F. Xue, M. Xu, B. S. Gui, F. X. Wang, and J. M. Ouyang, "Nanouric acid or nanocalcium phosphate as central nidus to induce calcium oxalate stone formation: a highresolution transmission electron microscopy study on urinary nanocrystallites," International Journal of Nanomedicine, vol. 9, no. 1, pp. 4399-4409, 2014.

[22] Y. Ou, J.-F. Xue, C.-Y. Tan, B.-S. Gui, X.-Y. Sun, and J.-M. Ouyang, "Inhibition of urinary macromolecule heparin on aggregation of Nano-COM and Nano-COD crystals," Molecules, vol. 20, no. 1, pp. 1626-1642, 2015.

[23] M. Marszałek, "Application of optical microscopy and scanning electron microscopy to the study of stone weathering: a cracow case study," International Journal of Architectural Heritage: Conservation, Analysis, and Restoration, vol. 2, no. 1, pp. 83-92, 2008.

[24] Y. Harada, T. Tomita, Y. Kokubo, H. Daimon, and S. Ino, "Development of an ultra high vacuum high resolution scanning transmission electron microscope," Journal of Electron Microscopy, vol. 42, no. 5, pp. 294-304, 1993.

[25] M. King, W. F. McClure, and L. C. Andrews, Powder Diffraction File Alphabetic Index, Inorganic Phases/Organic Phases, International Center for Diffraction Data, Newtown Square, Pa, USA, 1992.

[26] Y. M. F. Marickar, P. R. Lekshmi, L. Varma, and P. Koshy, "Elemental distribution analysis of urinary crystals," Urological Research, vol. 37, no. 5, pp. 277-282, 2009.

[27] P. G. Werness, J. H. Bergert, and L. H. Smith, "Crystalluria," Journal of Crystal Growth, vol. 53, no. 1, pp. 166-181, 1981.

[28] M. Robert, A.-M. Boularan, O. Delbos, L. Monnier, and D. Grasset, "Evaluation of the risk of stone formation: study on crystalluria in patients with recurrent calcium oxalate urolithiasis," European Urology, vol. 29, no. 4, pp. 456-461, 1996.

[29] M. Robert, A.-M. Boularan, O. Delbos, J. Guiter, and B. Descomps, "Study of calcium oxalate crystalluria on renal and vesical urines in stone formers and normal subjects," Urologia Internationalis, vol. 60, no. 1, pp. 41-46, 1998.

[30] U. Herrmann and P. O. Schwille, "Crystalluria in idiopathic recurrent calcium urolithiasis," Urological Research, vol. 20, no. 2, pp. 157-164, 1992. 
[31] G. Piccoli, D. Varese, and M. Rotunno, Eds., Atlas of Urinary Sediments, Raven Press, New York, NY, USA, 1984.

[32] J. Prywer and A. Torzewska, "Effect of curcumin against proteus mirabilis during crystallization of struvite from artificial urine," Evidence-Based Complementary and Alternative Medicine, vol. 2012, Article ID 862794, 7 pages, 2012.

[33] J. Prywer and A. Torzewska, "Bacterially induced struvite growth from synthetic urine: experimental and theoretical characterization of crystal morphology," Crystal Growth \& Design, vol. 9, no. 8, pp. 3538-3543, 2009.

[34] Q. He, X. C. Zhang, and Y. Q. Na, "Analysis of chemical composition of urinary stones and evaluation of metabolic disturbance in 284 patients," Chinese Journal of Urology, vol. 26, no. 11, pp. 761-764, 2005.

[35] S. Srinivasan, P. Kalaiselvi, R. Sakthivel, V. Pragasam, V. Muthu, and P. Varalakshmi, "Uric acid: an abettor or protector in calcium oxalate urolithiasis? Biochemical study in stone formers," Clinica Chimica Acta, vol. 353, no. 1-2, pp. 45-51, 2005.

[36] L. Chen, Y. H. Shen, A. Xie, F. Z. Huang, W. Q. Zhang, and S. X. Liu, "Seed-mediated synthesis of unusual struvite hierarchical superstructures using bacterium," Crystal Growth and Design, vol. 10, no. 5, pp. 2073-2082, 2010.

[37] R. Boistelle, F. Abbona, and H. E. L. Madsen, "On the transformation of struvite into newberyite in aqueous systems," Physics and Chemistry of Minerals, vol. 9, no. 5, pp. 216-222, 1983.

[38] C. K. Chauhan and M. J. Joshi, "In vitro crystallization, characterization and growth-inhibition study of urinary type struvite crystals," Journal of Crystal Growth, vol. 362, no. 1, pp. 330-337, 2013.

[39] K. Sternberg, S. P. Greenfield, P. Williot, J. Wan, B. Kogan, and S. G. Docimo, "Pediatric stone disease: an evolving experience," Journal of Urology, vol. 174, no. 4, pp. 1711-1714, 2005.

[40] L. Clapham, R. J. C. McLean, J. C. Nickel, J. Downey, and J. W. Costerton, "The influence of bacteria on struvite crystal habit and its importance in urinary stone formation," Journal of Crystal Growth, vol. 104, no. 2, pp. 475-484, 1990.

[41] F. Grases, A. Costa-Bauzá, M. Ramis, V. Montesinos, and A. Conte, "Simple classification of renal calculi closely related to their micromorphology and etiology," Clinica Chimica Acta, vol. 322, no. 1-2, pp. 29-36, 2002.

[42] E. Königsberger and Z.-H. Wang, "Solubility of uric acid in salt solutions and artificial urine," Monatshefte fur Chemie, vol. 130, no. 9, pp. 1067-1073, 1999.

[43] H. P. Lee, D. Leong, and C. T. Heng, "Characterization of kidney stones using thermogravimetric analysis with electron dispersive spectroscopy," Urological Research, vol. 40, no. 3, pp. 197-204, 2012. 

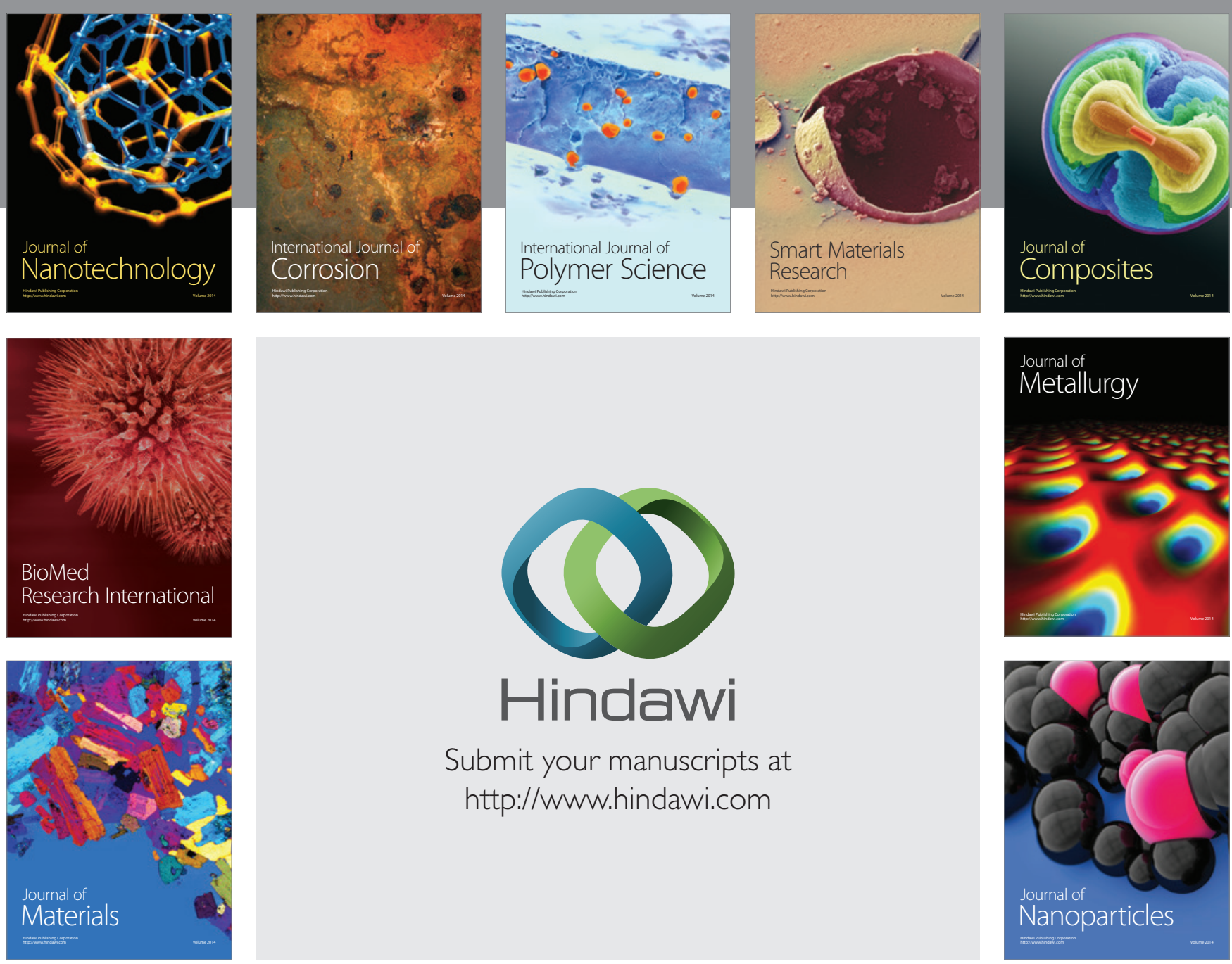

Submit your manuscripts at http://www.hindawi.com
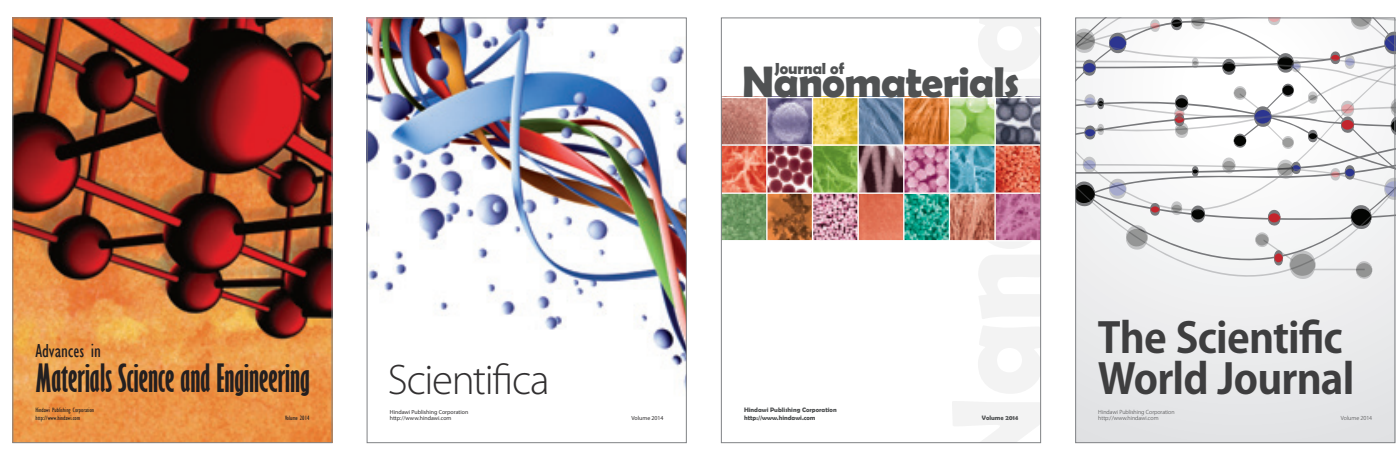

\section{The Scientific World Journal}
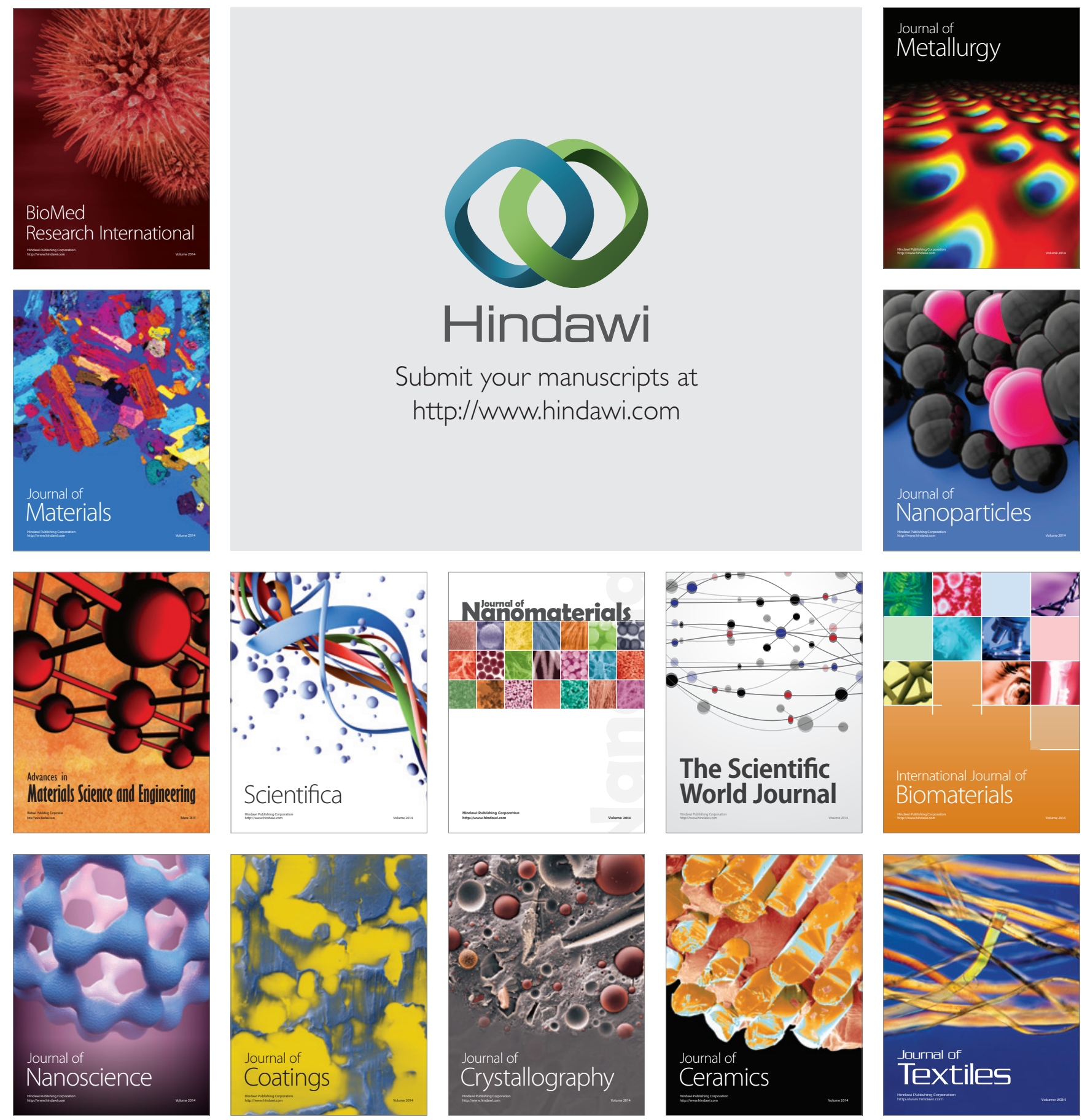